\title{
Trichoniscoides saeroeensis Lohmander, an Isopod Crustacean new to the British Fauna
}

\author{
By EDITH M. SHEPPARD ${ }^{1)}$
}

With plate 128 (1)

In a recent collection of cave Isopods forwarded to me for identification by Miss Mary Hazelton, Hon. Biological Recorde: of the Cave Research group of Great Britain, were some specimens which had been collected by Mr. C. M. Moseley from Grizedale Wood drainage Level and Crag Foot Mine and Moss House Mine in Lancashire.

The specimens from these localities were collected in the dark zone, those from Grizedale and Moss House occurred in damp, decaying timber, those from Crag Foot Mine were found on the surface film of a pool of clear water. These specimens proved to be Trichoniscoides saeroeensis Lohmander, a species not previously recorded in this country.

\section{Historical}

This very small terrestrial Isopod was first collected by Lohmander in June, 1922, from Sarö, in North Halland, S. Sweden; it occurred on the sea-shore, deep in humus-rich sand, under old cast-up weed lying at high water mark. Lohmander recognised that the first and second pleopods of the adult male differed from those of any other species of Trichoniscoides, and established the specific name $T$. saeroeensis to contain it. The species was recorded, without description in, Goteborgstraktens Landispoder the following year.

Lohmander obtained further specimens in May, 1924, at Kullaberg, in N. W. Schonen, where they occurred in large numbers at two different stations, one below the westermost coast rocks in places overgrown with grass, particularly Ameria maritima, a moderate distance from high water mark, under stones, in a deep layer of humus; the other, in a cave on the northern side of the hills, also under stones in damp humus. In his paper Lohmander (1924) describes and figures the first and second pleopods of the male but gives no detailed description of the species apart from a few notes on its size colour. Meinertz (1932) and Wachtler (1937) add nothing further

1) Department of Zoology, University College, Cardiff. 
to our knowledge, but Legrand (1949) records the species as new to the fauna of France, and gives some account of the pereiopods and also of the integument, and in addition discusses its affinities.

Vandel, in his paper on 'Isopodes terrestres' published in 1952, gives a complete list of the known localities from which T. saeroeensis had been collected and includes a map showing its distribution together with that of T. albidus (Budde-Lund) and T. sarsi Patience, the other two species of the genus occurring in the British Isles. Further references are listed at the end of this paper.

\section{Systematic position}

Vandel (1960, p. 96) outlines a classification of the families belonging to the sub-order Oniscoidea Sars and introduces a further division into superfamilies.

Trichoniscoides Sars is placed in the tribe Synocheta Legrand, depending on the form of the genital apophysis in the male, and in the super-family Trichoniscoidae Vandel and family Trichoniscidae Sars; the family was sub-divided further by Verhoeff and the genus placed in the sub-family Trichoniscinae, the systematics of which is based entirely on the form of the first and second male pleopods. Vandel (1960, p. 138) further subdivides this sub-family into three divisions, corresponding to three stages in the evolution of the first male pleopod. In the second of these divisions the endopodite of this pleopod usually carries a plumose seta at its tip; the division is very large and contains many genera and species which Vandel has grouped into five legions, and it is in the last of these that the genus Trichoniscoides is placed, together with the genera Scotoniscus Racovitza and Metatrichoniscoides Vandel. These three genera form a homogeneous group distinguished from all other Trichoniscids by the fact that the exopodite of the first male pleopod bears two, or more rarely three ciliated processes and the endopodite usually bears a single plumose seta.

TRICHONISCOIDES SAEROEENSIS Lohmander

T. saeroeensis Lohmander 1923, 24; Meinertz 1932, 1936; Wächtler 1937.

T. saeroeensis Legrand 1949; Vandel 1952, 1960.

\section{Description}

Size: ot, length $1.8-2 \mathrm{~mm}$; breadth $0.6-0.68 \mathrm{~mm}$; q, length $2.4 \mathrm{~mm}$, breadth $0.9 \mathrm{~mm}$.

Colouration: Mainly white but with some orange-red pigment along the mid-dorsal line and a little scattered on the head and lateral areas of the anterior pereion somites as well as on the pleon. The amount of pigmentation is, however, very variable from one individual to another. 
The body is narrow and rather convex dorsally and is about three times as long as broad; the lateral margins of the four anterior pereion somites are rounded posteriorly, those of the remaining three are produced backwards into acute points. The pleon is abruptly narrower than the pereion and is about one quarter of the length of the body. The form of the telson and usopods can be seen in text figure 1. The head is transversely oval in shape, about $1 \frac{1}{2}$ times as braod as long; there is only a slight development of lateral lobes. Eyes are absent, this agrees with Lohmander 1924 and Vandel $(1952,1960)$ but according to Legrand (1949) simple eyes, each consisting of a single ommatidium containing orange-red pigment (very soluble in alcohol), are present. I failed to find these in living specimens, but this could be associated with the fact that the specimens were collected from the dark zone of the mines. The dorsal surface of the body bears a number of tubercles which are scattered over the surface of the head but are disposed in three transverse rows on the first, and two on the remaining pereion somites; a single row is present on the segments of the pleon.

Microscopic examination shows that each tubercle carries a group of three short sheathed spines with a small one at its base. The margins of the head and tergites as well as some of the peduncle joints of the antenna also bear groups of three spines, interspersed with simple ones. The whole dorsal surface of the body is covered with scales, the free rounded margins of which are slightly thickened and have a comb-like appearance. These scales vary in shape according to their position on the tergite, for example, they are very narrow in the anterior region where the tergite is covered by the one in front, and are broadest in the middle region but in no place did they appear to be as angular as those illustrated by Legrand (1949, fig. 1). Scattered between these scales, are others from which arise single delicate setae these are also illustrated by Legrand (fig. 5) but I failed to find the "ecaille piliforme" illustrated by this author (fig. 2), in which a scale is shown bearing three groups of setae, accompanied by a short spine; neither did I find the very small simple "escaillete" (fig. 3).

Vandel (1960, p. 253) describes the integument fo this species as appearing to be quite smotoh when examined under a binocular but under the microscope it shows the presence of simple spines arranged in 2-3 rows on each tergite; this does not agree with the observations of Legrand (1949) or of my

The form of the antennule and antenna may be seen in text figure 2. The terminal joint of the antennule (Fig. A) is longer than the second, considerably narrower and curved, with three sensory filaments at its distal extremity, the flagellum of the antenna (Fig. B) consists of three joints, the second one of which is the longest and bears a group of three long sensory filaments.

The mouth parts bear a close resemblance to those of other species of the genus. 
I failed to find any sexual differences in the structure of the pereiopods although the carpus of the first pereiopod of one specimen did show the so called hyaline scales which Legrand (1949) states are present on the inner side of carpus of the first and second pereiopod of the male. This author also mentions, as another sexual difference, that the protopodite of the seventh pereiopod carries two spines in the male and three in the female and suggests that this difference is in keeping with the difference in size of the two sexes. In the specimens of the present collection the protopodite of the seventh pereiopod bears three spines in both sexes but only two are present on the protopodite of the fifth and sixth limbs. The protopodites of the first and second pereiopods differ from those of the remaining ones by the possession, in both sexes, of a row of five very small, somewhat flattened delicate spines directed distally; these lie immediately in front of the large spine near the base of the joint. The dactylus of each of the first four pereiopods bears a long spine with a rounded tip, which arises near the base of the joint and reaches almost to the extremity of the terminal spine.

The structure of the first two pairs of pleopods of the male and of the penis is shown in text figures. There is little to add to the descriptions already given by other authors. Legrand (1949) in his figure of the exopodite of the first pleopod shows the presence of a single central curved spine on the outer process, surrounded by delicate setae. There is a similar spine in this position on the inner process as well, but in neither case are they always easy to see and so can be overlooked. In one specimen examined, the right exopodite had three processes instead of the normal two, an anomaly previously recorded for $T$. mixtus Racovitza and $T$. davidi Racovitza as well as for T. albidus (Budde-Lund), noted by Patience (1908). Vandel (1960, p. 287) points out that this is a normal feature of the exopodite of species of Scotoniscus and concludes that this anomaly which has been recorded for the above species of Trichoniscoides, supports his view that the two genera show close affinities one with the other. The structure of the second pleopod (text fig. 30) is figured by most authors, its characteristic feature is the great length of the distal joint of the endopodite wich is $31 / 2-4$ times the length of the basal one. The basal third of the joint is conical in shape and I agree with Legrand (1949) that the narrowing of this region is brought about by the inrolling of its sides to enclose a groove which continues, according to Legrand, throughout the greater part of the length of the narrow distal twothirds. My own observations suggest that the inrolled edges in this narrow part meet over the groove and enclose it, thus, possibly, giving some support to this long delicate region. A short length behind the extremity is slightly curved and shows a fine crenulation of its margin under high magnification.

Vandel $(1952,1960$ p. 253) in referring to this joint makes no mention of a groove but describes the narrow distal part as consisting of a chitinous axis 
covered by a delicate hyaline membrane; it is possible that the support resulting from the inrolled edges mentioned above, might correspond with the axis described by Vandel.

The form of the first and second pleopod of the female has not been figured previously; the first pleopod (text fig. 3D) agrees very closely with the figure given by Meinertz (1933) for the corresponding pleopod of T. sarsi Patience, (Syn. T. albidus Sars, nec Budde-Lund); in that given by Sars (1899) the exopodite is shown as a much smaller structure. The endopodite of the second pleopod (text fig. $3 \mathrm{D}$ ) is more delicate than that shown by Meinertz for $T$. sarsi, and ends in a delicate bilobed extremity bearing six short setae.

The remaining pleopods are alike in both sexes; the fourth is very similar in shape to the fifth but the extremity of the exopodite is less pointed. Socalled hyaline scales separate small groups of setae on the outer border of the expodite of the fifth pleopod.

Affinities. According to Vandel $(1946,1952)$ this species shows affinities with certain Portuguese species, in particular with T. machadoi Vandel and $T$. ouremensis Vandel; Legrand (1949) agrees with the findings of Vandel and states that it is a clear cut member of the group machadoi - pseudomixtus. Its integumentary characters show an advance on those of $T$. machadoi where the integument is smooth but some simple spines are present and agress with those of $T$. pseudomixtus - meridionalis Vandel where comblike and piliform scales are developed. The first and second pleopods of the male are also very similar and according to Legrand the endopodite of the second pleopod of $T$. saeroeensis only differs from that of $T$. pseudomixtus meridionalis by the much greater length of the distal part.

\section{Origin and Distribution}

Our knowledge of the present distribution of this species has greatly increased since it was first collected from Southern Sweden by Lohmander (1923, 1924); it has been recorded from a number of Danish stations, also from Jutland and from the Baltic island of Bornham and the islands of Oland and Gotland as well as from the coast of Brittany.

It was first recorded as a member of the French fauna by Legrand (1949), where it had been collected from the sea shore at Grandville, near St. Brieuc, at St. Michel (Côtes du Nord) and from the littoral zone at Roscoff (Finistère); both Legrand and Vandel (1952) suggested that the species probably occurred along a much greater length of the French coast. Vandel (1952, 1960) emphasised that the species was strictly littoral and never occurred away from the sea shore, a statement which overlooks the fact that Lohmander (1924) collected specimens in damp humus from a cave 
on the northern side of the hills at Kullaberg in N. W. Schonen; presumably the species reached here from the littoral zone since Lohmander also obtained specimens in large numbers from below the westermost coast rocks at Kullaberg, at a moderate distance from highwater mark, under stones in a deep layer of humus.

I am greatly indebted to Mr. C. M. Moseley for the following information concerning the locality surrounding Warton Crag, where mining extends back to Elizabethan times at least, and probably earlier. The nearest river, the Keer, is about 2 miles away, but the mines from which the specimens were collected lie very close to a large marsh known as Storrs Moss; this is less than $25 \mathrm{ft}$. above sea level, and the two drainage levels (Moss House and Grizedale Wood) discharge into it. The sea proper is about $11 / 2$ miles away at normal high tide, but above this level are extensive salt flats which extend very near to the bottom of Walton Crag. These contain pools which vary in size and position from time to time, and their salt water content varies from very salt to almost freshwater, so that there is a shallow gradient from marine to terrestrial conditions. The mines themselves contain small natural cavities which are thought to date from Pre-Pleistocene times; thus, conditions in the area are such that this species, which is of normal littoral habit, would have been able to reach the mines and take on a cavernicolous mode of life, much in the same way as it did at Kullaberg. At this point it is worth comparing the distribution of Trichoniscoides saeroeensis with that of the other two species of the genus (T. albidus (Budde-Lund) and T. sarsi Patience) previously recorded in the British Isles, since, except for the supposed absence of $T$. saeroeensis from Great Britain, the three species have an almost identical distribution.

Vandel (1952), in his paper on Terrestrial Isopods points out that these three species are "true" expansive forms, which show a relatively stable morphology whilst possessing a great capacity for adapting themselves to varied climatic conditions; further, he places T. saeroeensis and T. albidus in his Atlantic group, members of which had their origin in the Iberian peninsula where the greatest number of species of the genus are still to be found. T. sarsi, which differs in certain morphological characters from members of the Atlantic group is placed in his group "Aquitano-languedocien", with the West coast of France as its place of origin.

The three species all occur in the littoral zone along this portion of the French coast where the necessary very humid conditions and the slight thermal seasonal variations are available, as well as in the proximity of maritime rivers where conditions are very similar. T. albidus extends further inland than either of the other two, and has been recorded from humid forests; T. sarsi shows a tendency to become cavernicolous in habit, both in France and in this country where it has been recorded from Gough's 
Cave, Cheddar (Collinge), but it is usually associated with river banks and the seashore. According to Vandel (1952) these two species appear to have spread into northern France from the west and reached the British Isles before the opening of the Pas-de-Calais; here their distribution is widespread, both species have been recorded from a number of English counties, including Lancashire, and from Scotland as far north as Inverness ( $T$. sarsi) as well as from the Isle of Man and the northern half of Ireland (only one record for $T$. sarsi). In his paper, Vandel includes a map showing the distribution of the three species, which have spread by another route to Northern Europe, all three are recorded at a number of stations in Denmark and southern Sweden; T. sarsi also occurs in S. Norway and Finland where it is restricted to greenhouses. T. albidus is recorded in Belgium, Holland and the Rhineland, and according to Vandel its northern limit is marked by the isotherm $0^{\circ}$ of January, further north it is only found in greenhouses. T. saeroeensis has not been recorded further north than S. Sweden. Before summing up, the question of the origin of the timber from which specimens of $T$. saeroeensis were collected from Grizedale Wood drainage level must not be overlooked, since imported timber may be responsible for the introduction of a species not previously recorded. I am agian indebted to Mr. Moseley for the trouble he has taken in obtaining information on this point; in a special report on Iron ores (Haematites of W. Cumberland, Lancashire and the Lake district) (Smith, 1916) is a statement that the Furness area local wood became scarce from 1778 onwards, and wood for timbering and mines was imported from Norway.

The mines on Warton Crag were worked from 1870 to the early part of the 20 th century by a very small company which appears to have been formed by the miners themselves, and it is questionable whether they would have used imported timber. Even if they did so, it is extremely unlikely that $T$. saeroeensis was introduced in this way since (1) it is normally a littoral species and (2) it has not been recorded from a region as far north as Norway. It seems logical to conclude therefore, that the species whose distribution so closely resembles $T$. albidus and $T$. sarsi, reached this country in the same way and at the same time, namely, before the opening of the Pas-de-Calais, as did these two species; this is further supported by the fact that all three species have now been recorded from Lancashire. It is possible that $T$. saeroeensis has a much wider distribution in this country, but owing to its very small size - it is one of the smallest Trichonescids known - it may well have been overlooked. A systematic investigation of the west coastal area covering the Barrow and Furness districts, suggested by Collinge (1945), particularly in the type of habitat $T$. saeroeensis is known to frequent, might well result in further records for this species. 


\begin{abstract}
The terrestial isopod Trichoniscoides saeroeensis Lohmander, new to the British fauna, is recorded from the dark zone of disused mines in Lancashire; the paper includes notes on its systematic position and certain morphological characters as well as its affinities. The origin and geographical distribution of the species, together with that of the other two species recorded in England [T. albidus (Budde-Lund) and $T$. sarsi Patience], is discussed.

\section{RÉSUMÉ}

L'Isopode terrestre Trichoniscoides saeroeensis Lohmander, nouveau pour la faune d'Angleterre, est signalé dans les parties obscures de plusieurs mines abandonnées du Lancashire. Des précisions sont apportées sur la position systématique, les affinités et certains caractères morphologiques de l'espèce. L'origine et la répartition géographique des trois espèces de Trichoniscoides rencontrées en Angleterre [T. albidus (Budde-Lund), T. sarsi Patience et T. saeroeensis Lohmander] sont discutées.
\end{abstract}

\title{
EXPLICATIONS OF PLATE 128 (1)
}

Fig. 1: Last pleon segment, telson and uropods $\times 95$.

Fig. 2: A. Antennule $\times 200$; B. Antenna $\times 100$.

Fig. 3: A. penis; B. First right pleopod $\left(0^{\star}\right)$; C. Second right pleopod $\left(0^{\star}\right)$; D. First ù left pleopod (()); E. Second left pleopod (ㅇ). All $\times 130$.

\section{REFERENCES}

Budde-Lund, G. (1879) - Prospectus generum specierunique Crustaceorum Isopodum terrestrium Copenhagen.

Collinge, W. E. (1945) - XCV On the Woodlice of Yorkshire. N. W. Nats. 1945, p. 7.

EDNEY, E. B. (1953) - The Woodlice of Great Britain and Ireland. A conside systematic Monograph. P. Linn, Soc. London, Session 164, 49-98.

Legrand, J. J. (1949) - Contribution a l'étude des Isopodes terrestres de la Bretagne. Bull. Soc. Zool. France LXXIV. 53-67.

- (1954) - Les Isopodes terrestres du Poitou et du littoral charentais. Contribution à l'étude du peuplement atlantique Mem. Mus. Hist. Nat. Paris, n. s. Ser. A. Zool., VI, 139-180.

LOHMANDER, H. (1923) - Goteborgstraktens Landisopoder. Ur Goteborgstrakens Natur. Göteborg, 408-420.

- (1924) - Trichoniscoides saeroeensis n. sp. Entomol. Tidskr., XLV, 80-82.

MeinerTz, H. (1932) - Die Landisopoden Dänemarks. I. Die Ligiiden und Trichonisciden. Zool. Jahrb. Abt. System. Gekel. Geogr., LXIII, 352-406.

- (1936) - Storkrebs II Ringkrebs 2. Baenkebidene (Land- og FerskvandsIsopoder). Danmarks Fauna. XLII, 1-92.

Patience, A .(1908) - On Trichoniscoides albidus (B-L) and T. sarsi (nom. nov.) Ann. Mag. Nat. Hist. Glasgow, Ser. 8. Vol. 2, 84-88.

SARS, G. O. (1899) - An account of the Crustacea of Norway. Vol. II, 164-166.

Smith, M. A. (1916) - Iron Ores: Haematites of West Cumberland, Lancashire and the Lake District. Special Reports on the Mineral Resources of Gt. Britain. Vol. VIII, p. 5.

VANDEL, A. (1946) - Crustacés Isopodes terrestres (Oniscoidea) épigés et cavernicoles du Portugal. Etude des récoltes de M. A. de Barros Machado. Anais Facul. Cienc. Porto, XXX, 135-427.

- (1952) - Isopodes terrestres (Troisième série) Biospeologica, LXXIII. Arch. Zool. exp. gen. LXXXVIII, $231-362$.

- (1960) - Faune de France 64. Isopodes Terrestres (Premiere Partie) 134-141, $240-254$.

WachtLer, W. (1937) - Isopoda. Asseln. Die Tierwelt Mitteleuropas, Leipzig, II. Band, Lief. 2 b, $251-254$. 


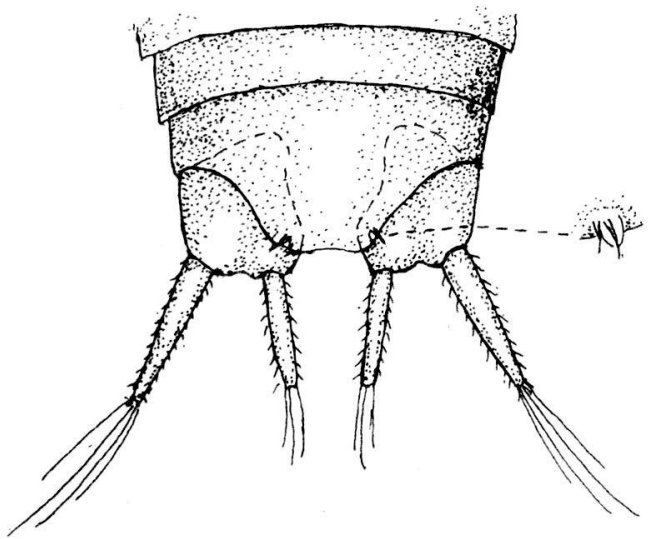

Fig. 1
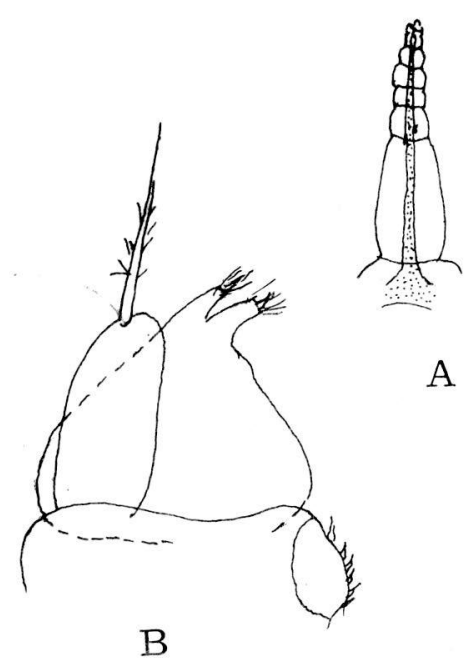

A

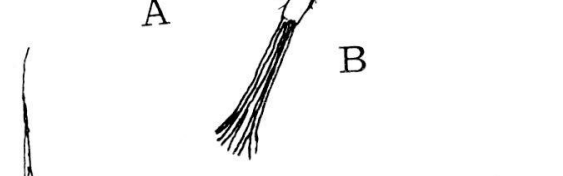

Fig. 2

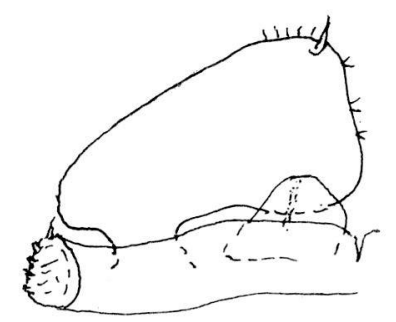

D

Fig. 3

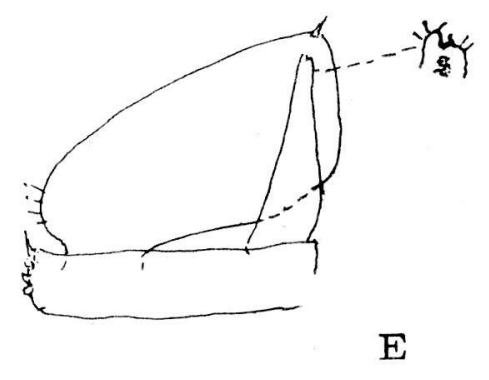

